\title{
EFFECT OF MICROWAVE RADIATION ON MICROORGANISMS IN FISH MEALS*
}

\author{
Justyna Bauza-Kaszewska ${ }^{1}$, Krzysztof Skowron $^{2 \star}$, Zbigniew Paluszak¹ ${ }^{1}$ Zbigniew Dobrzański ${ }^{3}$, \\ Mścisław Śrutek ${ }^{4}$ \\ ${ }^{1}$ Department of Microbiology and Food Technology, University of Technology and Life Sciences, \\ Bernardyńska 6-8, 85-029 Bydgoszcz, Poland \\ ${ }^{2}$ Department of Microbiology, Nicolaus Copernicus University in Toruń, Ludwik Rydygier Collegium \\ Medicum in Bydgoszcz, M. Skłodowskiej-Curie 9, 85-094 Bydgoszcz, Poland \\ ${ }^{3}$ Department of Environment Hygiene and Animal Welfare, Wroclaw University of Environmental \\ and Life Sciences, Chełmońskiego 38C, 51-630 Wrocław, Poland \\ ${ }^{4}$ Institute of Telecommunications and Computer Science, University of Technology and Life Sciences \\ in Bydgoszcz, Kaliskiego 7, 85-796 Bydgoszcz, Poland \\ •Corresponding author: skowron238@wp.pl
}

\begin{abstract}
This study was aimed at testing the effect of microwave radiation on survival of $E$. coli, Salmonella Enteritidis, Enterococcus spp. and Clostridium spores in two kinds of fish meals. The material used in the study consisted of samples of two kinds of fish meal - salmon and cod. In the experiment samples of both kinds of fish meals were inoculated with suspensions of tested bacteria and spores of Clostridum sporogenes. After inoculation the material was exposed to microwave radiation with a frequency of $2.45 \mathrm{GHz}$ and microwave energy power of $0,100,180,300,450,600$ and $700 \mathrm{~W}$, respectively, for $\mathbf{2 . 5} \mathrm{min}$ for bacteria and $\mathbf{1 1}$ minutes for spores. Then the reisolated microorganisms were counted and theoretical lethal doses of radiation were determined. Among the studied vegetative forms of bacteria, the largest decreases in the numbers at the same radiation dose were observed in the rods of $\boldsymbol{E}$. coli, whereas the smallest in enterococci. Spores of Clostridium sporogenes showed a considerably higher resistance to the effect of that factor. The power of dose resulting in the complete inactivation of the studied bacteria should be about $430 \mathrm{~kJ} \times \mathrm{g}^{-1}$, and in the case of spores $-1900 \mathrm{~kJ} \times \mathrm{g}^{-1}$.
\end{abstract}

Key words: microwave radiation, inactivation of bacteria, spores, fish meals

Microwave radiation is a common method of food processing. Cooking, drying, blanching and thawing with microwave reduces time of the process and, if properly planned, enables avoiding the losses of nutritional quality of the product (Dong et al., 2011; Ghanem et al., 2012; Chandrasekaran et al., 2013).

\footnotetext{
*The study was conducted within the research project No. NN209756840 financed by the National Science Centre, Poland.
} 
It was also proved that electromagnetic waves with a frequency from $300 \mathrm{MHz}$ to $300 \mathrm{GHz}$, have a lethal impact on a number of pathogenic microorganisms, both those occurring only at the vegetative stage (Salmonella spp., Listeria spp., Campylobacter spp.) and those that are able to form spores highly resistant to unfavourable outside factors (Clostridium spp., Bacillus spp.) (Welt et al., 1994; Dańczuk and Łomotowski, 2008; Wu and Yao, 2010; Lu et al., 2011). Bactericidal effect of microwaves is used for medical equipment sterilization, hospital waste disposal or inactivation of pathogens in food (Park et al., 2006; Zieliński et al., 2007).

It is assumed that one of the mechanisms determining the inhibitory efficacy of microwave radiation towards microorganisms is certainly the so-called thermal effect. It results from the high temperature generated during this process, causing irreversible changes in the structure of proteins, enzymes and nucleic acids inside the microbial cells. Also cytoplasmic membranes and the cell wall undergo destruction, which in turn results in leakage from cells components necessary for their proper functioning. It is also proven that weakening of bacteria cell membrane results in increasing bactericidal effectiveness of some antibiotics (Nasri et al., 2013).

It is disputable, in turn, if there exists a non-thermal effect, specific only to microwave radiation, which is questioned by some researchers. It would be responsible for microorganisms elimination under conditions of temperatures not exceeding their point of thermal death (Woo et al., 2000; Buffo and Holley, 2006; Shamis et al., 2008).

Due to relatively low costs and the simplicity of this method, attempts at its application are made in many different fields of economy. In the present study, the effect of microwave radiation on the microorganism survival rate in two types of fish meals was tested. These products, which are a rich source of protein in animal feeds, can be also a habitat for bacteria of the genus Salmonella (Crump et al., 2002; Møretrø et al., 2003; Maciorowski et al., 2007). For this reason, among others, it is necessary to subject them to appropriate methods of processing, minimizing the epidemiological risk connected with their utilization. The effectiveness of microwave rays allows for the assumption that under optimized conditions they can be used for efficient hygienization of animal meals.

\section{Material and methods}

The material used in the study consisted of samples of two kinds of fish meal salmon and cod. Cod meal contained on average $19.6 \%$ of total protein and $0.5 \%$ of crude fat. The content of Ca was 22-27\%, and P 13-14\%. Salmon meal contained on average $27.4 \%$ of crude protein and $1.8 \%$ of crude fat. The content of $\mathrm{Ca}$ was $16-25 \%$, and $\mathrm{P}$ was $11-12 \%$.

Production technology of these fish meals is the subject of a patent application at the Polish Patent Office (no. P-403123).

The submitted material was initially examined for presence of the total number of microorganisms, mould fungi, actinomycetes and rods of Salmonella spp., E. coli, enterococci and spores of sulfite reducing anaerobic bacteria. 
In the experiment samples of both kinds of fish meals were inoculated with suspensions of Salmonella Enteritidis, E. coli, bacteria of the genus Enterococcus and spores of Clostridium sporogenes IW1306 (PKM Wrocław). The study was conducted in 3 repetitions for each microorganism, both in cod and salmon meal.

Bacterial suspensions were prepared in sterile Ringer's solution based on 24-hour cultures of the studied bacteria on the nutritional agar. The density of each suspension was estimated using a densitometer at $0.3 \mathrm{McF}$.

To obtain spores suspension, $0.5 \mathrm{ml}$ of Clostridium sporogenes culture in BHI (Brain Heart Infusion) broth stored at $4^{\circ} \mathrm{C}$ was introduced to $10 \mathrm{ml}$ of the liquid FTG medium and incubated under anaerobic conditions (Anaerobic System, Oxoid) for 24 hours at $37^{\circ} \mathrm{C}$. Next $0.5 \mathrm{ml}$ of culture in FTG medium was transferred to $10 \mathrm{ml}$ of the Duncan-Strong medium and incubated under anaerobic conditions for 7 days at $37^{\circ} \mathrm{C}$. After that period, the inoculated Duncan-Strong medium was centrifuged at a speed of $3000 \mathrm{rpm}$ for 15 minutes, washed twice and suspended in $50 \mathrm{ml}$ sterile distilled water, obtaining a suspension with a density of $10^{7} \mathrm{CFU} \times \mathrm{ml}^{-1}$.

Next $1 \mathrm{ml}$ of individual bacterial suspensions and the spore suspension was added to samples of both types of fish meals with a weight of $7 \mathrm{~g}$ each, and then stirred to obtain a "dough" consistency. Inoculated material was dried for $45 \mathrm{~min}$ at $37^{\circ} \mathrm{C}$.

From dried samples of both types analytical samples with a mass of $0.5 \mathrm{~g}$ were prepared, which were scattered in a thin layer on ceramic trays with an area of $6.25 \mathrm{~cm}^{2}$. Then trays together with the material were exposed to microwave radiation with a frequency of $2.45 \mathrm{GHz}$ and microwave energy power $0,100,180,300$, 450,600 and $700 \mathrm{~W}$, respectively, for $2.5 \mathrm{~min}$ for bacteria and 11 minutes for spores. Taking into consideration the above data, the power of microwave radiation dose $\left(\mathrm{kJ} \times \mathrm{g}^{-1}\right)$ was calculated according to the equation:

$$
D=\frac{M \cdot t}{m}
$$

where:

$M$ - power of microwave energy $(\mathrm{kW})$,

$t$ - time of exposure (sec),

$m$ - mass of a sample subjected to exposure $(\mathrm{g})$.

The values of dose power, taking into account the effective radiation time, were presented in Table 1.

The number of all the studied bacteria was determined with the MPN (most probable number) method in a 3-tube set, making decimal dilutions of the radiated samples in appropriate media.

In the process of isolating rods of the genus Salmonella for initial multiplication ( 24 hours at $37^{\circ} \mathrm{C}$ ) $1 \%$ buffered peptonic water was used. Selective multiplication was carried out using the liquid medium according to Rappaport $\left(24\right.$ hours at $43^{\circ} \mathrm{C}$ ). For the growth on a solid medium, the selective agar BPLS agar medium was used (24 hours at $37^{\circ} \mathrm{C}$ ), on which Salmonella grew in the form of pale-pink colonies, dyeing the medium pink. Final identification consisted in the use of diagnostic sera according to the Kauffmann-White scheme. 
Table 1. Microwave radiation dose $\left(\mathrm{kJ} \times \mathrm{g}^{-1}\right)$

\begin{tabular}{|c|c|c|c|c|c|c|}
\hline \multicolumn{7}{|c|}{ Bacteria $-2.5 \mathrm{~min}$. } \\
\hline Microwave energy power $(\mathrm{kW})$ & 0.10 & 0.18 & 0.30 & 0.45 & 0.60 & 0.70 \\
\hline Effective radiation time (s) & 24.3 & 39.1 & 64.3 & 94.7 & 124.6 & 150.0 \\
\hline Microwave radiation dose $\left(\mathrm{kJ} \times \mathrm{g}^{-1}\right)$ & 4.86 & 14.08 & 38.58 & 85.23 & 149.52 & 210.00 \\
\hline \multicolumn{7}{|c|}{ Spores - $11 \mathrm{~min}$. } \\
\hline Microwave energy power $(\mathrm{kW})$ & 0.10 & 0.18 & 0.30 & 0.45 & 0.60 & 0.70 \\
\hline Effective radiation time (s) & 103.4 & 169.1 & 280.4 & 413.4 & 545.3 & 660.0 \\
\hline Microwave radiation dose $\left(\mathrm{kJ} \times \mathrm{g}^{-1}\right)$ & 20.68 & 60.88 & 168.24 & 372.06 & 654.36 & 924.00 \\
\hline
\end{tabular}

To determine the number of $E$. coli rods, a series of decimal dilutions was made on MacConkey's broth. Inoculated broth was incubated at $43^{\circ} \mathrm{C}$ for 24 hours. The change of medium colour from purple to yellow and the presence of gas in the Durham tube were assumed as the positive result. After the incubation of broth, the material was cultured on selective solid media - ENDO agar. Plates with the culture were incubated at $43^{\circ} \mathrm{C}$ for 24 hours. Typical growth of E. coli rods on ENDO agar had the form of dark red colonies with green-gold fuchsine sheen. Final identification was performed using the API 20E test.

Enterococci determination was performed using the broth with glucose and azide ( 48 hours at $37^{\circ} \mathrm{C}$ ) and agar with kanamycin, esculine and azide ( 48 hours at $37^{\circ} \mathrm{C}$ ). Turbidity of the liquid medium with glucose and azide indicated the presence of enterococci in the sample. On the solid media with kanamycin, the growth of small colonies and dyeing the medium for a dark colour indicated the presence of enterococci. Final identification was carried out based on the serological Phadabac Strep Test.

To estimate the number of Clostridium sporogenes spores in the studied material, a series of 10 -fold dilutions was prepared in tubes containing $9 \mathrm{ml}$ of peptonic water. Then, to inactivate vegetative forms, the tubes were placed in water bath at $80^{\circ} \mathrm{C}$ for 15 minutes. After cooling the tubes with dilutions, the number of spores was determined based on the results of cultures made with the pour-plate method. For this purpose, $1 \mathrm{ml}$ was taken 3 times from each dilution, introduced to sterile Petri dishes and poured with the DRCM medium solidified with agar. The cultures were incubated for 3 days at $37^{\circ} \mathrm{C}$ under anaerobic conditions. After the incubation, characteristic, black colonies of Clostridium sporogenes were counted on each plate.

Based on the results obtained, theoretical lethal doses, inactivation rate and doses causing a $90 \%$ reduction in the bacteria number were calculated. The theoretical lethal doses were calculated as the quotient of the intercept of the regression line equation (theoretical initial number of bacteria or spores at the beginning of process expressed in $\log$ MPN or $\log \mathrm{CFU}$ and the slope of the regression line (elimination rate)). In order, the $\mathrm{D}_{90}$ doses were determined as the quotient of the number of bacteria or spores equal $1 \log$ MPN or $\log$ CFU (90\% of population) and the slope of the regression line. 
The determined parameters were analysed statistically using the STATISTICA 10 PL (StatSoft $\left.{ }^{\circledR}\right)$ software, which involved the estimation of significance of differences between them at the levels 0.05 and 0.01 based on the Bonferroni test.

\section{Results}

The results of initial investigations did not show the presence of chosen indicator bacteria, fungi or actinomycetes in the material samples. The total number of microorganisms did not exceed the value of $10^{1} \mathrm{CFU} \times \mathrm{g}^{-1}$.

In the course of the conducted investigation, the sanitization of fish meal with the use of microwave radiation was proved to be effective. The results obtained made it possible to observe a gradual elimination of vegetative bacterial forms and the inactivation of Clostridium sporogenes spores along with an increase in a dose (Tables 2-5).

The initial number of the studied bacteria and spores remained at the level of $10^{6}-10^{7} \mathrm{MPN} \times \mathrm{g}^{-1}$ or $\mathrm{CFU} \times \mathrm{g}^{-1}$ (Tables $\left.2-5\right)$.

Table 2. Changes in number of Salmonella Enteritidis depending on microwave dose

\begin{tabular}{|c|c|c|}
\hline \multirow{3}{*}{$\begin{array}{c}\text { Dose } \\
\left(\mathrm{kJ} \times \mathrm{g}^{-1}\right)\end{array}$} & \multicolumn{2}{|c|}{ Number of Salmonella Enteritidis $\left(\mathrm{MPN} \times \mathrm{g}^{-1}\right)$} \\
\hline & \multicolumn{2}{|c|}{ type of fish meal } \\
\hline & $\operatorname{cod}$ & salmon \\
\hline Control sample & $2.0 \times 10^{7}$ & $1.5 \times 10^{7}$ \\
\hline 4.86 & $1.5 \times 10^{3}$ & $3.0 \times 10^{3}$ \\
\hline 14.08 & $2.5 \times 10^{2}$ & $9.5 \times 10^{2}$ \\
\hline 38.58 & $2.5 \times 10^{1}$ & $2.5 \times 10^{2}$ \\
\hline 85.23 & n.d.* & $2.5 \times 10^{1}$ \\
\hline 149.52 & n.d. & n.d. \\
\hline 210.00 & n.d. & n.d. \\
\hline
\end{tabular}

$*$ - not detected.

Table 3. Changes in number of $E$. coli depending on microwave dose

\begin{tabular}{|c|c|c|}
\hline \multirow{3}{*}{ 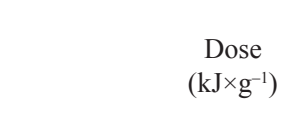 } & \multicolumn{2}{|c|}{ Number of $E$. coli $\left(\mathrm{MPN} \times \mathrm{g}^{-1}\right)$} \\
\hline & \multicolumn{2}{|c|}{ type of fish meal } \\
\hline & $\operatorname{cod}$ & salmon \\
\hline Control sample & $2.0 \times 10^{7}$ & $1.5 \times 10^{6}$ \\
\hline 4.86 & n.d. & $4.5 \times 10^{2}$ \\
\hline 14.08 & n.d. & $2.5 \times 10^{1}$ \\
\hline 38.58 & n.d. & n.d. \\
\hline 85.23 & n.d. & n.d. \\
\hline 149.52 & n.d. & n.d. \\
\hline 210.00 & n.d. & n.d. \\
\hline
\end{tabular}


Table 4. Changes in number of Enterococcus spp. depending on microwave dose

\begin{tabular}{|c|c|c|}
\hline \multirow{3}{*}{$\begin{array}{c}\text { Dose } \\
\left(\mathrm{kJ} \times \mathrm{g}^{-1}\right)\end{array}$} & \multicolumn{2}{|c|}{ Number of Enterococcus spp. (MPN $\left.\times \mathrm{g}^{-1}\right)$} \\
\hline & \multicolumn{2}{|c|}{ type of fish meal } \\
\hline & cod & salmon \\
\hline Control sample & $2.5 \times 10^{6}$ & $4.5 \times 10^{6}$ \\
\hline 4.86 & $2.0 \times 10^{5}$ & $2.5 \times 10^{5}$ \\
\hline 14.08 & $2.5 \times 10^{4}$ & $2.5 \times 10^{5}$ \\
\hline 38.58 & $2.5 \times 10^{3}$ & $2.5 \times 10^{4}$ \\
\hline 85.23 & $2.5 \times 10^{3}$ & $4.5 \times 10^{3}$ \\
\hline 149.52 & $2.5 \times 10^{3}$ & $2.5 \times 10^{3}$ \\
\hline 210.00 & $2.5 \times 10^{2}$ & $2.5 \times 10^{3}$ \\
\hline
\end{tabular}

Table 5. Changes in number of Clostridium sporogenes spores depending on microwave dose

\begin{tabular}{l|c|c}
\hline \multirow{2}{*}{\begin{tabular}{c}
\multirow{2}{*}{$\begin{array}{c}\text { Dose } \\
\left(\mathrm{kJ} \times \mathrm{g}^{-1}\right)\end{array}$} \\
\cline { 2 - 3 }
\end{tabular}} & \multicolumn{2}{|c}{ Number of $C$. sporogenes spores $\left(\mathrm{CFU} \times \mathrm{g}^{-1}\right)$} \\
\cline { 2 - 3 } & \multicolumn{2}{|c}{ type of fish meal } \\
\hline Control sample & $5.00 \times 10^{6}$ & salmon \\
20.68 & $3.63 \times 10^{6}$ & $5.83 \times 10^{6}$ \\
60.88 & $3.57 \times 10^{6}$ & $4.20 \times 10^{6}$ \\
168.24 & $2.83 \times 10^{6}$ & $4.03 \times 10^{6}$ \\
372.06 & $1.03 \times 10^{6}$ & $2.10 \times 10^{6}$ \\
654.36 & $2.50 \times 10^{5}$ & $5.96 \times 10^{5}$ \\
924.00 & $4.70 \times 10^{2}$ & $1.43 \times 10^{3}$ \\
\hline
\end{tabular}

The largest decreases in the number of the studied bacteria were observed in the case of E. coli, and the smallest for enterococci (Tables 2-4). Already a dose of $4.86 \mathrm{~kJ} \times \mathrm{g}^{-1}$ resulted in elimination of $E$. coli in the cod meal, and in the salmon meal the analogous effect was obtained at a dose of $38.58 \mathrm{~kJ} \times \mathrm{g}^{-1}$ (Table 3 ). The complete elimination of bacteria of the genus Enterococcus, in turn, was not observed, and

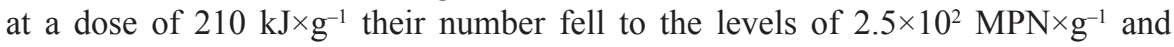
$2.5 \times 10^{3} \mathrm{MPN} \times \mathrm{g}^{-1}$ in the cod and salmon meals, respectively (Table 4). In the case of Salmonella Enteritidis rods, the complete elimination was observed in the case of microwave radiation dose equal to $85.23 \mathrm{~kJ} \times \mathrm{g}^{-1}$ in the cod meal and $149.52 \mathrm{~kJ} \times \mathrm{g}^{-1}$ in the salmon meal (Table 2).

Spores of Clostridium sporogenes were not fully inactivated within the studied range of microwave radiation doses (Table 5). At the dose of $924 \mathrm{~kJ} \times \mathrm{g}^{-1}$ the number of active spores was $4.70 \times 10^{2} \mathrm{CFU} \times \mathrm{g}^{-1}$ in the cod meal and $1.11 \times 10^{3} \mathrm{CFU} \times \mathrm{g}^{-1}$ in the salmon meal (Table 5).

Based on regression line equations (Figures 2-5), the theoretical lethal doses and $\mathrm{D}_{90}$ doses were determined, as well as the elimination rate for the studied vegetative bacterial forms and Clostridium sporogenes spores. 
Table 6. Statistical parameters describing the inactivation kinetics of selected microorganisms

\begin{tabular}{|c|c|c|c|c|}
\hline $\begin{array}{l}\text { Fish meal } \\
\text { type }\end{array}$ & Bacteria & $\begin{array}{l}\text { Theoretical lethal dose } \\
\qquad\left(\mathrm{kJ} \times \mathrm{g}^{-1}\right)\end{array}$ & $\begin{array}{c}\text { Elimination rate } \\
\left(\log \mathrm{MPN} \times\left(\mathrm{kJ} \times \mathrm{g}^{-1}\right)^{-1}\right)\end{array}$ & $\begin{array}{r}\mathrm{D}_{90} \text { dose } \\
\left(\mathrm{kJ} \times \mathrm{g}^{-1}\right)\end{array}$ \\
\hline \multirow[t]{5}{*}{ Cod } & S. Enteritidis & $\begin{array}{l}76.92 \mathrm{~A}, \mathrm{a} \\
( \pm 1.52)^{*}\end{array}$ & $\begin{array}{l}0.06 \mathrm{~A}, \mathrm{a} \\
( \pm 0.005)\end{array}$ & $\begin{array}{l}16.18 \mathrm{~A}, \mathrm{~F}, \mathrm{a} \\
( \pm 1.32)\end{array}$ \\
\hline & E. coli & $\begin{array}{l}6.50 \mathrm{~B}, \mathrm{~b} \\
( \pm 0,05)\end{array}$ & $\begin{array}{l}1.83 \mathrm{~B}, \mathrm{~b} \\
( \pm 0.02)\end{array}$ & $\begin{array}{c}0.55 \mathrm{~B}, \mathrm{~b} \\
( \pm 0.01)\end{array}$ \\
\hline & Enterococcus spp. & $\begin{array}{l}373.02 \mathrm{C}, \mathrm{c} \\
( \pm 13.02)\end{array}$ & $\begin{array}{l}0.01 \mathrm{~A}, \mathrm{c}, \mathrm{e} \\
( \pm 0.001)\end{array}$ & $\begin{array}{l}72.99 \mathrm{C}, \mathrm{c} \\
( \pm 5.40)\end{array}$ \\
\hline & & $\left(\mathrm{kJ} \times \mathrm{g}^{-1}\right)$ & $\left(\log\right.$ MPN $\left.\times\left(k J \times g^{-1}\right)^{-1}\right)$ & $\left(\mathrm{kJ} \times \mathrm{g}^{-1}\right)$ \\
\hline & C. sporogenes spores & $\begin{array}{l}1872.62 \mathrm{D}, \mathrm{d} \\
( \pm 59.46)\end{array}$ & $\begin{array}{l}0.004 \mathrm{C}, \mathrm{d} \\
( \pm 0.0001)\end{array}$ & $\begin{array}{l}270.27 \mathrm{D}, \mathrm{d} \\
( \pm 4.11)\end{array}$ \\
\hline \multirow[t]{5}{*}{ Salmon } & S. Enteritidis & $\begin{array}{l}136.86 \mathrm{E}, \mathrm{e} \\
( \pm 2.74)\end{array}$ & $\begin{array}{c}0.03 \mathrm{~A}, \mathrm{a}, \mathrm{c} \\
( \pm 0.002)\end{array}$ & $\begin{array}{c}29.59 \mathrm{~A}, \mathrm{e} \\
( \pm 1.34)\end{array}$ \\
\hline & E. coli & $\begin{array}{c}36.24 \mathrm{~F}, \mathrm{f} \\
( \pm 0.79)\end{array}$ & $\begin{array}{l}0.13 \mathrm{~A}, \mathrm{f} \\
( \pm 0.01)\end{array}$ & $\begin{array}{l}7.72 \mathrm{~B}, \mathrm{~F}, \mathrm{f} \\
( \pm 0.29)\end{array}$ \\
\hline & Enterococcus spp. & $\begin{array}{l}428.90 \mathrm{G}, \mathrm{g} \\
\quad( \pm 8.14)\end{array}$ & $\begin{array}{l}0.01 \mathrm{~A}, \mathrm{c}, \mathrm{e} \\
( \pm 0.001)\end{array}$ & $\begin{array}{l}76.92 \mathrm{C}, \mathrm{c} \\
( \pm 3.02)\end{array}$ \\
\hline & & $\left.\left(\mathrm{kJ} \times \mathrm{g}^{-1}\right)\right]$ & $\left(\log \mathrm{MPN} \times\left(\mathrm{kJ} \times \mathrm{g}^{-1}\right)^{-1}\right)$ & $\left(\mathrm{kJ} \times \mathrm{g}^{-1}\right)$ \\
\hline & C. sporogenes spores & $\begin{array}{l}1528.38 \mathrm{H}, \mathrm{h} \\
( \pm 14.79)\end{array}$ & $\begin{array}{l}0.005 \mathrm{C}, \mathrm{d} \\
( \pm 0.0002)\end{array}$ & $\begin{array}{l}222,22 \mathrm{E}, \mathrm{g} \\
\quad( \pm 5.08)\end{array}$ \\
\hline
\end{tabular}

A, B, C,.. - highly significant difference $(\mathrm{P} \leq 0.01)$.

$\mathrm{a}, \mathrm{b}, \mathrm{c}, \ldots-$ significant difference $(\mathrm{P} \leq 0.05)$.

* - standard deviation.

Theoretical lethal doses were highly significantly lower $(\mathrm{P} \leq 0.01)$ in the case of E. coli than for the other studied bacteria (Table 6). They amounted to 6.50 and

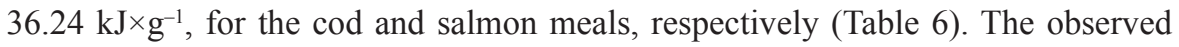
difference resulting from the type of fish meal was highly significant $(\mathrm{P} \leq 0.01)$ (Table 6).

Theoretical lethal doses calculated for Salmonella Enteritidis were highly significantly different $(\mathrm{P} \leq 0.01)$ both in comparison with $E$. coli, and with enterococci (Ta-

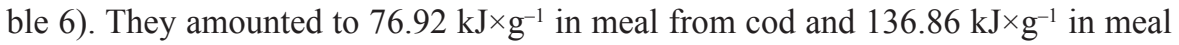
from salmon (Table 6). The difference connected with the type of meal was highly significant $(\mathrm{P} \leq 0.01)$ (Table 6).

Highly significantly higher $(\mathrm{P} \leq 0.01)$ theoretical lethal doses, as compared with the other bacteria, were found in the case of enterococci and they amount-

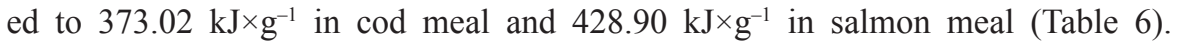
The difference connected with the meal type was highly significant $(\mathrm{P} \leq 0.01)$ (Table 6).

Theoretical lethal doses needed for the inactivation of Clostridium sporogenes spores were definitely higher $(\mathrm{P} \leq 0.01)$ as compared with vegetative forms of all the studied bacteria (Table 6). They amounted to as much as 1872.62 and $1528.38 \mathrm{~kJ} \times \mathrm{g}^{-1}$ in the meal from cod and salmon, respectively, whereas the difference resulting from the meal type was highly significant $(\mathrm{P} \leq 0.01)$ (Table 6). 
The calculated inactivation rate of microorganisms of the Enterococcus spp. was the lowest of the vegetative bacteria forms and was equal to $0.01 \log \mathrm{MPN} \times$ $\times\left(\mathrm{kJ} \times \mathrm{g}^{-1}\right)^{-1}$, both in the cod and salmon meals (Table 6). The highest inactivation rate, in turn, was observed in the case of $E$. coli rods and it was $1.83 \log$ MPN $\times$ $\times\left(\mathrm{kJ} \times \mathrm{g}^{-1}\right)^{-1}$ in the meal from cod and $0.13 \log \mathrm{MPN} \times\left(\mathrm{kJ} \times \mathrm{g}^{-1}\right)^{-1}$ from salmon (Table 6). Statistically significant $(\mathrm{P} \leq 0.05)$ or highly significant $(\mathrm{P} \leq 0.01)$ differences in the elimination rate resulting from the genus of bacteria in the given type of meal were observed between E. coli and the other microorganisms, whereas those connected with the meal type were also recorded only in the case of E. coli rods (Table 6). Spores of Clostridium sporogenes underwent a highly significantly $(\mathrm{P} \leq 0.01)$ slower elimination in comparison with vegetative forms of bacteria, and a difference in the inactivation rate resulting from the type of fish meal was not statistically significant $(\mathrm{P}>0.05)$ (Table 6).

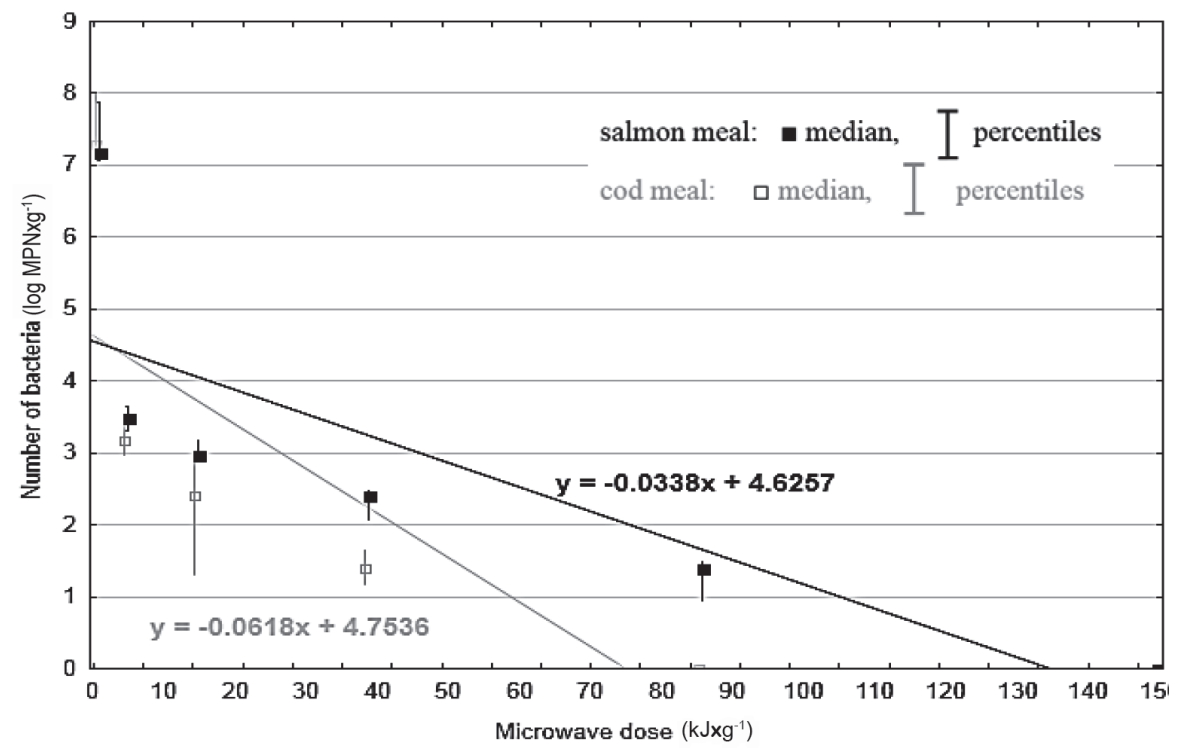

Figure 1. Regression lines describing the inactivation of Salmonella Enteritidis

Based on regression equations (Figures 1-4), microwave radiation doses causing a reduction in the number of the studied bacteria population by $90 \%\left(D_{90}\right)$ were calculated (Table 6). Reduction in the population number of vegetative forms of bacteria by $90 \%$ required the highest $\mathrm{D}_{90}$ dose $\left(72.99-76.92 \mathrm{~kJ} \times \mathrm{g}^{-1}\right)$ in the case of

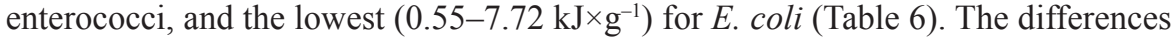
shown between the studied microorganisms in the given type of meal were highly significant $(\mathrm{P} \leq 0.01)$ (Table 6). In turn differences resulting from the type of fish meal were statistically significant $(\mathrm{P} \leq 0.05)$ in the case of Salmonella Enteritidis and E. coli (Table 6). 


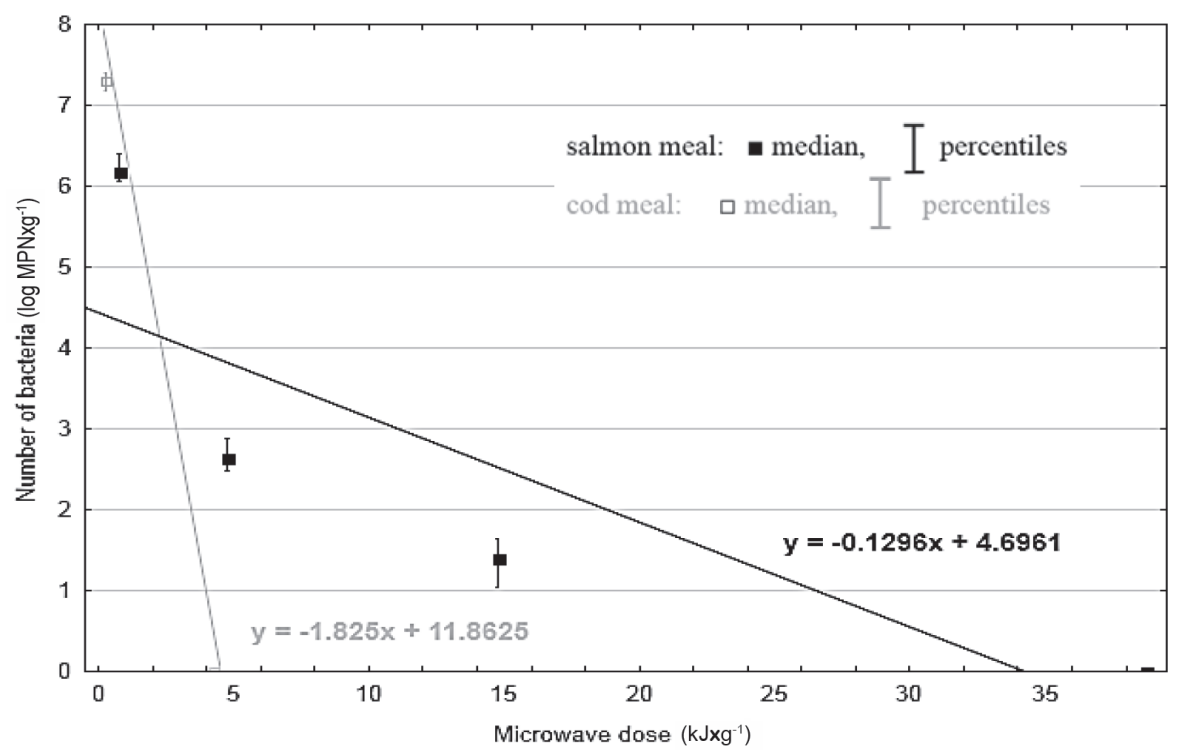

Figure 2. Regression lines describing the inactivation of $E$. coli

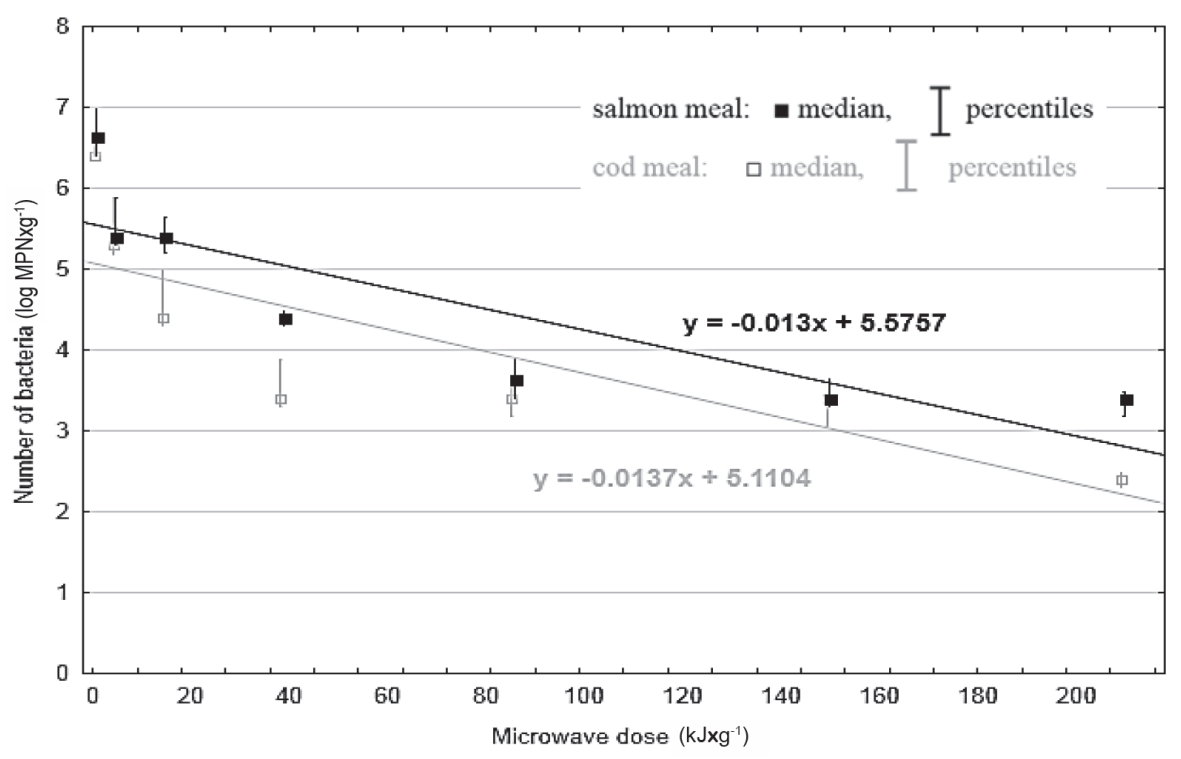

Figure 3. Regression lines describing the inactivation of Enterococcus spp. 


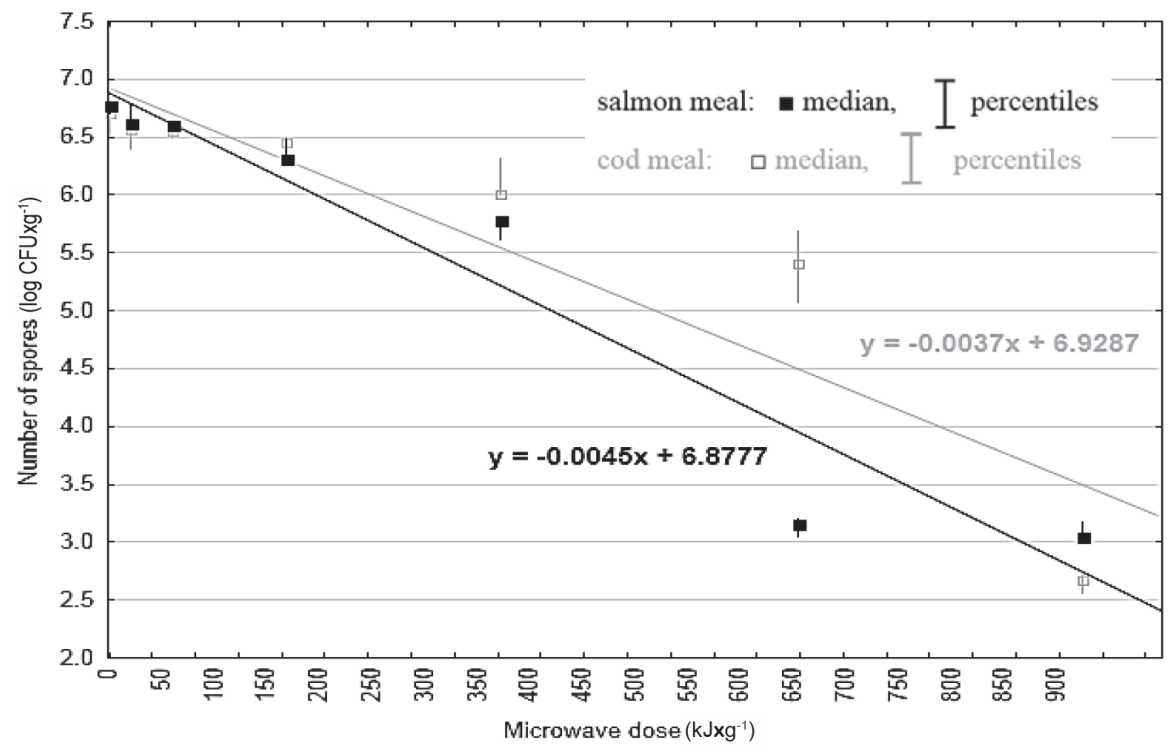

Figure 4. Regression lines describing the inactivation of Clostridium sporogenes spores

In the case of Clostridium sporogenes spores, $\mathrm{D}_{90}$ doses were highly significantly

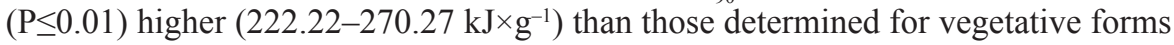
of the studied bacteria, and the difference resulting from the type of fish meal was highly significant $(\mathrm{P} \leq 0.01)$ (Table 6).

The results obtained allowed the conclusion that for vegetative forms of the studied bacteria higher theoretical lethal doses and $\mathrm{D}_{90}$ doses of microwave radiation at a lower elimination rate were recorded in the meal from salmon than that from cod (Table 6). By contrast, a reverse tendency was shown for Clostridium sporogenes spores (Table 6).

\section{Discussion}

The effective use of microwave radiation for inactivation of microorganisms is dependent on many factors. The basic outside parameters determining the bactericidal effectiveness of microwaves include their power, frequency, the time of action and temperature (Shamis et al., 2008).

In the present study, the highest degree of reduction under the influence of microwave radiation was observed in the case of $E$. coli, which died in the cod meal already after the application of $4.86 \mathrm{~kJ} \times \mathrm{g}^{-1}$ (Table 3). The most resistant of vegetative forms turned out to be enterococci, isolated in both types of meals even after the application of a dose of $210 \mathrm{~kJ} \times \mathrm{g}^{-1}$ (Table 4). Also for other hygienization methods, Salmonella spp. was more resistant than E. coli. According to Nardi et al. (2011) the 
UV dose needed for complete inactivation of Salmonella spp. reached $320 \mathrm{~J} \times \mathrm{m}^{-2}$ and, compared to $E$. coli $-110 \mathrm{~J} \times \mathrm{m}^{-2}$, appeared to be relatively high. Slightly different tendencies concerning differences in bacteria susceptibility to microwaves were observed by Dańczuk and Łomotowski (2008). The results of their study proved that a radiation dose necessary for the complete inactivation of Salmonella spp. in sewage is lower than that for the coliform bacteria. Both of them died after the application of a relatively low dose of radiation, not exceeding $12 \mathrm{~kJ} \times \mathrm{g}^{-1}$. According to Maktabi et al. (2011) reduction of $E$. coli viable counts after $15 \mathrm{~s}$ of microwave radiation ranged from 0.17 to $0.81 \log \mathrm{CFU} \times \mathrm{ml}^{-1}$ and was relatively low, compared to Pseudomonas fragi (2.00-3.27 log $\mathrm{CFU} \times \mathrm{ml}^{-1}$ ). The most effective antibacterial action against E. coli was achieved after combined treatment of laser, microwave and UV radiation. Their synergistic effect resulted in over $5 \log$ reduction of $E$. coli counts (Maktabie et al., 2011).

In the study by Hong et al. (2004), a 90-second action of microwaves leading to generating a temperature of about $65^{\circ} \mathrm{C}$ resulted in the complete inactivation of coliform bacteria in sewage sludge. Obtaining a similar result using conventional heating required considerably longer time and a temperature of $100^{\circ} \mathrm{C}$. Also Woo et al. (2000) reports that in the case of inactivation using microwaves a growth of temperature within the range from $50^{\circ} \mathrm{C}$ to $60^{\circ} \mathrm{C}$ is essential. Above this value, the effectiveness of the process of thermal reduction of $E$. coli and vegetative cells of B. subtilis was lower. De La Vega-Miranda et al. (2012) achieved 5 log cycles reduction of Salmonella Typhimurium in jalapeño pepper subjected to microwave treatment $\left(25 \mathrm{~s}, 63^{\circ} \mathrm{C}, 950 \mathrm{~W}\right)$. Inactivation of Salmonella Typhimurium in the yolk of artificially infected eggs pasteurized with microwave radiation for $20 \mathrm{~s}$, reached the value of about $1.2 \log$ (Shenga et al., 2010).

A number of studies also confirm the possibility of obtaining the inhibitory effect of microwave radiation even below $45^{\circ} \mathrm{C}$. Shamis et al. (2008), using a radiation source with the frequency of $18 \mathrm{GHz}$ and the power of $16 \mathrm{~W}$, obtained more than $60 \%$ degree of decontamination of raw meat surface inoculated with E. coli and Staphylococcus aureus. They also proved that at a high frequency of waves, repeating of irradiation allows for obtaining an increase in its bactericidal effectiveness.

The easily obtained thermal effect of microwave radiation makes it possible to predict its high effectiveness in inactivation of vegetative microbial forms. It is different in the case of spore forms, which sometimes are characterized by a very high thermoresistance, hindering their thermal destruction.

As expected, the results of the present study showed a considerably higher resistance of Clostridium sporogenes spores to the action of microwave radiation, in comparison with the other tested microorganisms. The dose equal to $210 \mathrm{~kJ} \times \mathrm{g}^{-1}$, which resulted in the complete inactivation of Salmonella Enteritidis and E. coli rods and a considerable reduction in the population of enterococci, did not exert a considerable effect on a change in the number of Clostridium spores (Table 5). The calculated theoretical radiation dose necessary to eliminate them was almost $1900 \mathrm{~kJ} \times \mathrm{g}^{-1}$ in the cod meal and slightly higher than $1500 \mathrm{~kJ} \times \mathrm{g}^{-1}$ in the salmon meal (Table 6).

Higher resistance of Clostridium spores to microwaves is also confirmed by Dańczuk and Łomotowski (2008). According to Kim et al. (2009), microwave radia- 
tion leads to an increase in pressure inside $C$. sporogenes spores and their mechanical destruction. This process is accompanied by releasing DNA and $\mathrm{Ca}$ ions from the inside of spores. Leakage of proteins and DNA was also observed after irradiation of spores of Bacillus licheniformis. The presence of DNA in the bacterial cell suspension, both at the vegetative and spore stages, indicates damage of their cytoplasmic membranes (Woo et al., 2000). Such changes were not caused by conventional boiling and a lower power of radiation used by Kim et al. (2009).

Optimization of irradiation process parameters is not the absolute guarantee of hygienization efficacy of microwave radiation. In the case of food products, their chemical composition, volume, structure, $\mathrm{pH}$ and water content are also of great importance (Canumir et al., 2002; Valsechi et al., 2004). The low activity of water and high fat content contribute to an increase in the microorganism thermoresistance (Anaya et al., 2008).

Similar factors may determine the inhibitory effect of microwaves on microorganisms contained in the studied fish meals. The present study indicates the presence of highly significant differences in the survival of the studied microorganisms in different meal types. However, whereas enterococci, Salmonella Enteritidis and $E$. coli rods were isolated longer from the salmon meal irradiated with microwaves, Clostridium spores underwent a slower elimination in the cod meal (Table 6).

Studies on the possibility of using microwave radiation in the food industry prove its high effectiveness in reducing the number of pathogenic microorganisms, including also those of the genus Salmonella. Many authors, however, focus particular attention on problems connected with uneven distribution of the heat generated during the process, and appearance of the so-called hot and cold spots in irradiated food. This refers mostly to products with large sizes and irregular shapes, and is connected with the risk of some pathogenic microorganisms surviving (Lu et al., 2011; Pucciarelli and Benassi, 2005; Aziz et al., 2002).

A serious disadvantage related to using microwave for food disinfection is the possible deterioration of the radiated product. The undesired changes include chemical composition, nutritional quality and sensory properties of food. However, there are many data confirming relatively low, compared to conventional heat-treatment, effect of microwave processing on the quality of food (Chandrasekaran et al., 2013). Properly established and controlled parameters of the radiation may guarantee both high quality of the product and its microbiological safety (Tochampa et al., 2011).

The use of microwave radiation for hygienization of contaminated fish meal turned out to be a relatively effective method both towards vegetative and spore forms of bacteria, but species differences in resistance were observed. The power of dose resulting in the complete inactivation of the studied bacteria should be about $430 \mathrm{~kJ} \times \mathrm{g}^{-1}$ (but only $140 \mathrm{~kJ} \times \mathrm{g}^{-1}$ for Salmonella Enteritidis and E. coli), and in the case of spores $-1900 \mathrm{~kJ} \times \mathrm{g}^{-1}$.

Homogeneous structure of meat and meat-and-bone meals allows for their even distribution, and then the control of thickness of the layer exposed to radiation. Together with the bactericidal effectiveness proved in the experiments, this can make an argument in favour of conducting further studies towards the use of microwaves as an effective method for sanitization of meat and fish meals. 


\section{References}

A na y a I.I., Agu irrezab a 1 A.A., Ventura M.M., Com e 11 a s L.L., Agut M.M. (2008). Survivability of Salmonella cells in popcorn after microwave oven and conventional cooking. Microbiol. Res., 163: 73-79.

A z i z N.H., M a hrou s S.R., You s s e f B.M. (2002). Effect of gamma-ray and microwave treatment on the shelf-life of beef products stored at $5^{\circ} \mathrm{C}$. Food Control, 13: 437-444.

B uffo R.A., Holley R.A. (2006). Effects of food processing on disease agents. In: Food borne infections and intoxications, Riemann H.P., Cliver D.O. (eds). Elsevier Academic Press, UK, pp. 713-802.

Canumir J.A., Celis J.E., de Bruijn J., Vidal L.V. (2002). Pasteurisation of apple juice by using microwaves. Lebensm.-Wiss. Technol., 35: 389-392.

Chandrasekaran S., R a man athan S., Tanmay B as ak (2013). Microwave food processing - a review. Food Res. Int., 52: 243-261.

Crump J.A., Griffin P.M., Angulo F.J. (2002). Bacterial contamination of animal feed and its relationship to human foodborne illness. Clin. Infect. Dis., 35: 859-865.

D a ń c z u k M., Ł o m o t o w s k i J. (2008). Application of the microvare energy to the hygienization of sewage sludge (in Polish). Inż. Ochr. Środ., 11: 95-104.

De La Vega-Miranda B., Santiesteban-Lopez N.A., Lopez-Malo A., Sos a-Mo$\mathrm{rales}$ M. E. (2012). Inactivation of Salmonella Typhimurium in fresh vegetables using waterassisted microwave heating. Food Control, 26: 19-22.

D ong J., Ma X., F u Z., Gu o Y. (2011). Effects of microwave drying on the contents of functional constituents of Eucommia ulmoides flower tea. Ind. Crop. Prod., 34: 1102-1110.

Ghanem N., Mihoubi D., Kechaou N., Mihoubi N.B. (2012). Microwave dehydration of three citrus peel cultivars: Effect on water and oil retention capacities, color, shrinkage and total phenols content. Ind. Crop. Prod., 40: 167-177.

Hong S.M., Park J.K., L e e Y.O. (2004). Mechanisms of microwave irradiation involved in the destruction of fecal coliforms from biosolids, Water Res., 38: 1615-1625.

K i m S.Y., S h in S.J., S o n g C.H., J o E.K., K i m H.J., P a r k J.K. (2009). Destruction of Bacillus licheniformis spores by microwave irradiation. J. Appl. Microbiol., 106: 877-885.

L u Y., Turley A., D ong X., W u C. (2011). Reduction of Salmonella enterica on grape tomatoes using microwave heating. Int. J. Food Microbiol., 145: 349-352.

Maciorowski K.G., Herrera P., Jones F.T., Pilla i S.D., Ricke S.C. (2007). Effects on poultry and livestock of feed contamination with bacteria and fungi. Anim. Feed Sci. Tech., 133: 109-136.

Makt a bi e S., Wat s on I., P a rt on R. (2011). Synergistic effect of UV, laser and microwave radiation or conventional heating on $E$. coli and on some spoilage and pathogenic bacteria. Innov. Food Sci. Emerg. Technol., 12: 129-134.

Møretrø T., M id tg a a r E E.S., N e s s e L.L., L a n g s ru d S. (2003). Susceptibility of Salmonella isolated from fish feed factories to disinfectants and air-drying at surfaces. Review Vet. Microbiol., 94: 207-217.

Nard i I.R., N e ry V., A morim A.K.B., S antos N.G., Chimenes F. (2011). Performances of SBR, chemical-DAF and UV disinfection for poultry slaughterhouse wastewater reclamation. Desalination, 269: 184-189.

N a sri K., Da gh fou s D., Land ouls i A. (2013). Effects of microwave (2.45 GHz) irradiation on some biological characters of Salmonella Typhimurium. C.R.Biol., 336: 194-202.

Park D.K., B itton G., Melker R. (2006). Microbial inactivation by microwave radiation in the home environment. J. Environ. Health., 69: 17-24.

Pu c c i a re 11 i A.B., B en a s i F.O. (2005). Inactivation of Salmonella enteritidis on raw poultry using microwave heating. Braz. Arch. Biol. Technol., 48: 939-945.

Sham is Y., Taube A., Shramkov Y., Mitik-Dineva N., Vu B., Ivanova E.P. (2008). Development of a microwave treatment technique for bacterial decontamination of raw meat. Int. J. Food Eng., 4: 359-371.

Shenga E., Singh R.P., Yadav A.S. (2010). Effect of pasteurization of shell egg on its quality characteristics under ambient storage. J. Food Sci. Technol., 47: 420-425. 
Tochampa W., Jittrepotch N., Kongbangkerd T., Kraboun K., Rojsuntornkit $t$ i K. (2011). The study of microwave heating time on chemical and microbiological properties and sensory evaluation in sweet fermented glutinous rice (Khao-Mark). Int. Food Res. J., 18: 239-248.

Valsechi A.O., Horii J., Angelis D. (2004). The effect of microwaves on microorganisms. Arquivos do Instituto Biológico, Sao Paulo, 71: 399-404.

W e 1 t B.A., T o n g C.H., R o s s e n J.L., L u n d D.B. (1994). Effect of microwave radiation on inactivation of Clostridium sporogenes (PA 3679) spores. Appl. Environ. Microbiol., 60: 482-488.

W o o I.S., R h e e I.K., P a r k H.D. (2000). Differential damage in bacterial cells by microwave radiation on the basis of cell wall structure. Appl. Environ. Microbiol., 66: 2243-2247.

Wu Y., Yao M. (2010). Inactivation of bacteria and fungus aerosols using microwave irradiation. J. Aerosol Sci., 41: 682-693.

Zieliński M., Ciesielski S., Cydzik-Kwiatkowska A., Turek J., Dębowski M., (2007). Influence of microwave radiation on bacterial activity and community structure in biofilm. Process Biochem., 42: 1250-1253.

Received: 4 VIII 2013

Accepted: 26 XI 2013 